\title{
Study of sodium arsenite induced biochemical changes on certain biomolecules of the freshwater catfish Clarias batrachus
}

\author{
Randhir Kumar and Tarun K. Banerjee
}

Toxic impact of sublethal concentration $\left(1 \mathrm{mg} / \mathrm{L} ; 5 \%\right.$ of $96 \mathrm{~h} \mathrm{LC}_{50}$ value $)$ of sodium arsenite $\left(\mathrm{NaAsO}_{2}\right)$ on certain biomolecules (proteins, nucleic acids, lipids, and glycogen) of five tissue components (muscles, liver, brain, skin, and gills) of the freshwater catfish Clarias batrachus was analysed. The important toxic manifestations include marked decrease in the concentration of proteins (21.72-45.42\% in muscles; $3.42-53.94 \%$ in liver; $15.39-45.42 \%$ in brain; $15.40-4.00 \%$ in skin and $11.35-64.13 \%$ in gills), DNA (0.55-22.95\% in muscles; $8.33-14.06 \%$ in liver; $5.30-18.40 \%$ in brain; $13.57-52.80 \%$ in skin; and $12.38-31.01 \%$ in gills), RNA (42.68-76.16\% in muscles; $10.68-39.75 \%$ in liver; 5.66-29.05\% in brain; $7.72-27.93 \%$ in skin and $21.47-44.38 \%$ in gills) and glycogen (24.00-51.72\% in muscles; $49.11-72.45 \%$ in liver; $11.49-26.03 \%$ in brain; $26.13-38.05 \%$ in skin and $17.80-37.97 \%$ in gills). Excepting liver where the lipid content increases (15.82-24.13\%), the fat content also showed depletion in their concentration (10.40-29.83\% in muscles; $8.30-34.45 \%$ in brain; $8.94-31.47 \%$ in skin and $12.75-28.86 \%$ in gills), in the rest of the organ systems.

Foi analisado o impacto tóxico da concentração subletal ( $1 \mathrm{mg} / \mathrm{L} ; 5 \%$ do valor de LC50 de 96h) do arsenito de sódio (NaAsO2) sobre certas biomoléculas (proteinas, ácidos nucleicos, lipídios e glicogênio) de cinco tecidos (músculos, fígado, cérebro, pele e brânquias) do bagre Clarias batrachus. As manifestações tóxicas importantes incluiram o decréscimo acentuado na concentração de proteinas $(21,72-45,42 \%$ nos músculos; $3,42-53,94 \%$ no fígado; $15,39-45,42 \%$ no cérebro; $15,40-4,00 \%$ na pele e 11,35-64,13\% nas brânquias), DNA (0,55-22,95\% nos músculos; 8,33-14,06\% no fígado; 5,30-18,40\% no cérebro; 13,57$52,80 \%$ na pele e $12,38-31,01 \%$ nas brânquias), RNA (42,68-76,16\% nos músculos; 10,68-39,75\% no fígado; 5,66-29,05\% no cérebro; $7,72-27,93 \%$ na pele e $21,47-44,38 \%$ nas brânquias) e glicogênio (24,00-51,72\% nos músculos; 49,11-72,45\% no fígado; $11,49-26,03 \%$ no cérebro; $26,13-38,05 \%$ na pele e $17,80-37,97 \%$ nas brânquias). Excetuando o fígado onde o conteúdo de lipídeos aumentou (15,82-24,13\%), houve uma depleção na concentração de lipídeos no restante dos sistemas orgânicos (10,40-29,83\% nos músculos; $8,30-34,45 \%$ no cérebro; $8,94-31,47 \%$ na pele e $12,75-28,86 \%$ nas brânquias).

Key words: Glycogen, Lipids, Nucleic acids, Proteins, Toxicity.

\section{Introduction}

There has been a continuous and alarming influx of arsenic to aquatic environment worldwide from both naturally occurring and anthropogenic sources (Goering et al., 1999). More than one hundred million people are at high risk of elevated arsenic exposure, mainly via drinking water, as well as by the air born metalloid in the areas with coal burning and industrial emissions. Consumption of the arsenic contaminated fishes collected from the polluted waters might also contribute to bioaccumulation of arsenic in human beings. Hence it is of immense importance to know the arsenic induced damages in the different organ systems of fishes used for human consumption. In an effort to achieve this, the toxicity analyses of an arsenic salt (sodium arsenite) on certain important biomolecules (proteins, nucleic acids, lipids, and glycogen) of various organ systems (gills, skin, liver, brain, and muscles) were performed.

In aquatic environment arsenic exists either in arsenite $\left(\mathrm{As}^{3+}\right)$ or arsenate $\left(\mathrm{As}^{5+}\right)$ form, which is inter-converted through redox and methylation reactions (Eisler, 1988; Philips, 1994). Of these arsenic in $\mathrm{As}^{5+}$ form is the least toxic while $\mathrm{As}^{3+}$ has been found to be more harmful both under in vivo and in vitro conditions (Cervantes et al., 1994). The data related to toxicity of arsenic on fishes are scanty (Leah et al., 1992; Ghosh et al., 2006; Bhattacharya et al., 2007; Singh \& Banerjee, 2007; Kavitha et al., 2010; Kumar \& Banerjee, 2012). These data however do not reflect the damage caused to the various biomolecules of physiological importance. Hence in this study efforts have been made to analyse the arsenic induced damage caused to proteins, nucleic acids, lipids, and glycogen of certain organs (Table 15) of Clarias batrachus a popular catfish of great food value of

Banaras Hindu University, Eco-physiology Unit, Department of Zoology, Varanasi-221 005, India. randhir18bhu@gmail.com (RK), tkbzool@yahoo.co.in (TKB) 
the Indian subcontinent. Because nucleic acids are very important in maintaining the physiological configuration of the fish, arsenic induced alterations in the DNA and RNA levels have also been evaluated.

\section{Material and Methods}

\section{Animal care and maintenance}

Freshwater catfish Clarias batrachus (Linnaeus, 1758) weighing $45 \pm 5 \mathrm{~g}$ were purchased from the local fish market at Chaukaghat Varanasi during month of November 2008. The fish were acclimated in tap water (having dissolved $\mathrm{O}_{2} 6.3 \mathrm{mg} /$ $\mathrm{L}, \mathrm{pH} 7.2$, water hardness $23.2 \mathrm{mg} / \mathrm{L}$ and room temperature $28 \pm 3^{\circ} \mathrm{C}$ ) for 21 days under laboratory conditions. Feeding was allowed after every $24 \mathrm{~h}$ during the entire period of acclimation as well as the experimentation. Water from both control as well as experimental tubs were renewed regularly four hour after every feeding.

\section{Experimental design}

Twenty groups of 10 fish each were exposed separately to a sublethal concentration ( $1 \mathrm{mg} / \mathrm{L} ; 5 \%$ of $96 \mathrm{~h} \mathrm{LC}_{50}$ value) (Kavitha et al., 2010) of sodium arsenite (Batch $\mathrm{N}^{\circ} \mathrm{G} 270707$ Loba Chemie Pvt. Ltd. Mumbai, minimum assay 98.5-102.0\%) in large plastic tubs containing 10 liters of the test solution prepared in the tap water following $24 \mathrm{~h}$ renewal bioassay technique. Tap water was selected because survival duration of the exposed fish did not vary in the test solution prepared in different types of water like distilled, pond and tap waters. Control fish were retained in 10 liters of plain tap water (without having the arsenic salt) under identical laboratory conditions. For toxicity analyses three sets of experiment (control as well as experiment) groups were run. Three fish from all the experimental as well as control aquaria were cold anesthetized and sacrificed by spinal dislocation after the expiry of 0 day, $10,30,45$, and 60 days of exposure. Entire brain, liver, gills, and small fragments of muscle and skin were dissected out and washed in fish saline before processing.

\section{Biochemical analyses}

For preparation of extracts, tissue samples were homogenised in $20 \%$ TCA (10\% tissue homogenate) and centrifuged at $5000 \mathrm{rpm}$ for 10 minutes at $4{ }^{\circ} \mathrm{C}$ for estimating of proteins and nucleic acids. The step was repeated once to eliminate the acid soluble substances. Pellet thus obtained was re-dissolved in 95\% ethanol and centrifuged again at $5000 \mathrm{rpm}$ for 10 minutes at $4^{\circ} \mathrm{C}$. This step was repeated once to eliminate the lipid moieties. The supernatant was discarded and the pellet thus obtained was finally dissolved and retained in $5 \%$ TCA for 10 minutes at $90^{\circ} \mathrm{C}$ and centrifuged at $7000 \mathrm{rpm}$ at $4^{\circ} \mathrm{C}$ for 10 minutes. The pellet was digested in $0.5 \mathrm{~N} \mathrm{NaOH}$ at $90^{\circ} \mathrm{C}$ in water bath for 15 minutes and centrifuged at 7000 rpm at $4^{\circ} \mathrm{C}$ for 10 minutes and the clear solution obtained was used for protein estimation (Lowry et al., 1951).

Total DNA was estimated by the diphenylamine method (Schneider, 1957). Calf-thymus DNA was used as a standard.
Total RNA was estimated by the orcinol method (Schneider, 1957) using yeast RNA as a standard. For analyses of total lipids tissue samples were subjected to extraction in chloroform methanol mixture (2:1) following the method of Folch \& Stanely (1957). Glycogen content was analysed following the method of Carroll et al. (1956). The tissue samples were digested in $30 \% \mathrm{KOH}$ in a water bath at $90^{\circ} \mathrm{C}$ for 30 minutes. The digested samples were cooled overnight at $4^{\circ} \mathrm{C}$ and precipitated with $95 \%$ ethyl alcohol and centrifuged for 15 minutes at $1200 \mathrm{~g}$. This step was repeated twice. Finally the residues containing glycogen were dissolved in distilled water and measured using anthrone reagent. Glucose was used as a standard.

\section{Statistical analysis}

Two-way ANOVA followed by Dunnett's $t$-test was performed to detect the level of significance at $5 \%$ of error probability $(\mathrm{P}<0.05)$ between the treated and untreated fish groups by using the SPSS software.

\section{Results}

Fluctuations were observed in the amount of protein, nucleic acid, lipid, and glycogen contents in all the five tissues at different time intervals of exposure (Table1-5).

\section{Skin}

The amount of proteins in the skin of unexposed control fish ranged between $69.22 \pm 0.99 \mathrm{mg} / \mathrm{g}$ (in November) to $72.22 \pm 0.96 \mathrm{mg} / \mathrm{g}$ (in January). Following exposure the protein contents of the skin decreased significantly throughout the period of exposure (Table 1).The DNA content in skin of unexposed control fish fluctuated between $4.74 \pm 0.13$ to $5.36 \pm 0.03 \mathrm{mg} / \mathrm{g}$. In exposed tissue after an initial increase (after 10 days), the DNA content decreased progressively as well as significantly. The cutaneous RNA content of unexposed fish also fluctuated and ranged between $3.90 \pm 0.18$ to $3.33 \pm 0.044$ $\mathrm{mg} / \mathrm{g}$. The level of RNA in the exposed skin remained below the control level throughout the period of experiment. The decrease was statistically very significant after 60 days. Lipid contents in unexposed controls ranged between $21.32 \pm 0.60 \mathrm{mg} / \mathrm{g}$ (in November) to $21.64 \pm 0.37 \mathrm{mg} / \mathrm{g}$ (in January). After an initial increase following 10 days of exposure, the lipid contents of skin progressively decreased throughout the period of exposure. The decrease was statistically very significant after 60 days of exposure period. The amount of glycogen in the skin of unexposed control fish ranged between $4.83 \pm 0.197 \mathrm{mg} /$ $\mathrm{g}$ (in November) to $4.73 \pm 0.069 \mathrm{mg} / \mathrm{g}$ (in January). After an initial increase following 10 days of the exposure, the glycogen content progressively decreased throughout the period of exposure. The decrease was statistically very significant after 60 days of exposure (Table 1 ).

\section{Gills}

The amount of proteins in the gills of unexposed control fish ranged between $40.88 \pm 1.16 \mathrm{mg} / \mathrm{g}$ in November to $43.66 \pm 1.01 \mathrm{mg} / \mathrm{g}$ in January, when the protein level increased 
Table 1. Fluctuations in different biomolecules in the skin of Clarias batrachus at different period of exposure to $1 \mathrm{mg} / \mathrm{L}$ of sodium arsenite. Protein, DNA, RNA, lipid, and glycogen were expressed in $\mathrm{mg} / \mathrm{gm}$ wet wt of tissue. Data are shown as mean \pm SEM $(\mathrm{n}=9)$. (\%) Denote changes over respective controls. Two way ANOVA followed by Dunnett's $t$-test. The criterion for significance differences set at $\left(^{*}\right) p<0.05,\left({ }^{* *}\right) p<0.01$ and $\left(^{* * *}\right) p<0.001$ with respective control. $\left({ }^{\text {a }}\right)$ Indicates when exposed groups were compared with 0 day controls and $(\mathrm{b})$, when exposed groups were compared with previous exposed group.

\begin{tabular}{|c|c|c|c|c|c|c|}
\hline \multirow{2}{*}{ Biomolecules } & \multirow{2}{*}{ Treatments } & \multicolumn{5}{|c|}{ Periods (days) } \\
\hline & & 0 & 10 & 30 & 45 & 60 \\
\hline \multirow{2}{*}{ Protein } & Control & $69.22 \pm 0.996$ & $71.44 \pm 0.929$ & $71.55 \pm 1.167$ & $71.33 \pm 1.054$ & $72.22 \pm 0.968$ \\
\hline & Exposed & $69.22 \pm 0.996$ & $\begin{array}{c}60.44 \pm 1.692^{* * *_{a}} \\
(-15.39 \%)\end{array}$ & $\begin{array}{c}55.00 \pm 0.866^{* * *_{a}, \mathrm{~b}} \\
(-23.13 \%)\end{array}$ & $\begin{array}{c}44.66 \pm 0.897^{* * *_{a}, \mathrm{~b}} \\
(-37.39 \%)\end{array}$ & $\begin{array}{c}33.22 \pm 1.288^{* * *_{a}, \mathrm{~b}} \\
(-54 \%)\end{array}$ \\
\hline \multirow{2}{*}{ DNA } & Control & $4.74 \pm 0.128$ & $4.83 \pm 0.101$ & $5.01 \pm 0.076$ & $5.56 \pm 0.044$ & $5.36 \pm 0.033$ \\
\hline & Exposed & $4.74 \pm 0.128$ & $\begin{array}{c}5.6 \pm 0.076^{\mathrm{a}} \\
(+15.94 \%)\end{array}$ & $\begin{array}{c}4.33 \pm 0.072^{*} \\
(-13.57 \%)\end{array}$ & $\begin{array}{c}3.4 \pm 0.057^{* a} \mathrm{a} \\
(-38.85 \%)\end{array}$ & $\begin{array}{c}2.53 \pm 0.060^{* a} \\
(-52.80 \%)\end{array}$ \\
\hline \multirow{2}{*}{ RNA } & Control & $3.90 \pm 0.180$ & $3.76 \pm 0.109$ & $3.37 \pm 0.092$ & $3.83 \pm 0.192$ & $3.33 \pm 0.044$ \\
\hline & Exposed & $3.90 \pm 0.180$ & $\begin{array}{c}3.3 \pm 0.028 \\
(-12.23 \%)\end{array}$ & $\begin{array}{c}3.11 \pm 0.028 \\
(-7.72)\end{array}$ & $\begin{array}{c}3.21 \pm 0.086^{\mathrm{a}} \\
(-16.18 \%)\end{array}$ & $\begin{array}{c}2.4 \pm 0.076^{* a, b} \\
(-27.92)\end{array}$ \\
\hline \multirow[b]{2}{*}{ Lipid } & Control & $21.32 \pm 0.606$ & $21.05 \pm 0.580$ & $20.94 \pm 0.340$ & $20.81 \pm 0.403$ & $21.64 \pm 0.374$ \\
\hline & Exposed & $21.32 \pm 0.606$ & $\begin{array}{c}27.30 \pm 1.42^{* a} \\
(+29.69 \%)\end{array}$ & $\begin{array}{c}26.72 \pm 0.469^{*} \\
(+27.60 \%) \\
\end{array}$ & $\begin{array}{c}18.95 \pm 0.629^{*}, \mathrm{~b} \\
(-8.93 \%) \\
\end{array}$ & $\begin{array}{c}14.83 \pm 0.673^{* * *} \\
(-31.47 \%) \\
\end{array}$ \\
\hline \multirow{2}{*}{ Glycogen } & Control & $4.83 \pm 0.197$ & $4.22 \pm 0.126$ & $4.63 \pm 0.242$ & $4.79 \pm 0.118$ & $4.73 \pm 0.076$ \\
\hline & Exposed & $4.83 \pm 0.197$ & $\begin{array}{c}4.98 \pm 0.132^{* *} \\
(+18 \%)\end{array}$ & $\begin{array}{c}3.42 \pm 0.115^{* *_{\mathrm{a}, \mathrm{b}}} \\
(-26.13 \%)\end{array}$ & $\begin{array}{c}3.32 \pm 0.098^{* * * a} \\
(-30.68 \%)\end{array}$ & $\begin{array}{c}2.93 \pm 0.130^{* * * a, b} \\
(-38.05 \%)\end{array}$ \\
\hline
\end{tabular}

slightly. In exposed fish the protein contents decreased progressively throughout the period of exposure. All the decreases were statistically significant. The DNA content in gills of unexposed control fish showed periodic fluctuations (between $7.13 \pm 0.08$ to $6.9 \pm 0.13 \mathrm{mg} / \mathrm{g}$ ). In exposed fish after an initial increase (after 10 days), the DNA content of the gills progressively decreased which were statistically significant. The RNA content in unexposed control fish showed periodic fluctuation ( $7.03 \pm 0.06$ to $7.30 \pm 0.07 \mathrm{mg} / \mathrm{g}$ ). On exposure the RNA content of gills increased initially and remained above the control level up to 30 days. Subsequently it decreased progressively and got reduced significantly after 45 days (Table 2). The lipid contents in unexposed control fish fluctuated in a narrow range $(24.77 \pm 0.314 \mathrm{mg} / \mathrm{g}$ (in November) to $24.44 \pm 0.68 \mathrm{mg} / \mathrm{g}$ (in January). Following exposure the lipid contents decreased progressively throughout the tenure of the experiment. The decreases were statistically significant during the entire period of exposure (Table 2). The amount of glycogen in the gills of unexposed control fish ranged between $4.62 \pm 0.166 \mathrm{mg} / \mathrm{g}$ to $4.01 \pm 0.117 \mathrm{mg} / \mathrm{g}$. After an initial increase (10 days of the exposure), the glycogen content of skin progressively decreased throughout the period of exposure. The decrease was statistically very significant after 60 days (Table 5).

\section{Liver}

The amount of proteins in the liver of unexposed control fish fluctuated between $80.78 \pm 2.21 \mathrm{mg} / \mathrm{g}$ (in November) to $88.78 \pm 1.16 \mathrm{mg} / \mathrm{g}$ (in January). The protein contents in the liver of exposed fish decreased progressively throughout the period of exposure (Table 3 ). The decreases after 30 days onwards of exposure were highly significant. The DNA content in liver of unexposed fish fluctuated (between $2.56 \pm 0.04$ to $2.63 \pm 0.04 \mathrm{mg}$ / g) throughout the period of experimentation. Following exposure it (DNA content) decreased progressively (Table 3 ). The RNA content in liver of unexposed control fish showed periodic fluctuations (between $0.90 \pm 0.007$ to $0.96 \pm 0.006 \mathrm{mg} / \mathrm{g}$ ). Following exposure the RNA content decreased progressively throughout the period of treatment (Table 3). Lipid contents of unexposed control fish fluctuated at different experimental period and ranged between $55.33 \pm 0.91 \mathrm{mg} / \mathrm{g}$ in the initial stages of the experiment (in November) to $56.06 \pm 1.03 \mathrm{mg} / \mathrm{g}$ after 60 days (in January). Excepting after 45 days, the lipid contents of exposed fish remained above the control level throughout the period of experimentation. The alterations were also statistically significant at all the stages of exposure. The amount of glycogen in the liver of unexposed control fish fluctuated between $33.58 \pm 0.621 \mathrm{mg} / \mathrm{g}$ (in November) to $32.311 \pm 0.889 \mathrm{mg} / \mathrm{g}$ (in January). The glycogen contents in the liver of exposed fish decreased progressively throughout the period of exposure. The decrease in glycogen was highly significant (Table 3 ).

\section{Brain}

The amount of proteins in the brain of unexposed control fish ranged between $35.11 \pm 0.89 \mathrm{mg} / \mathrm{g}$ (November) to $41.33 \pm 1.66 \mathrm{mg} / \mathrm{g}$ (January). In the exposed tissue the protein contents after an initial increase (10 days of exposure) decreased steadily throughout the period of exposure (Table 4). The DNA content in unexposed control fish during the 60 days of observation also showed periodic fluctuation (between $1.46 \pm 0.04$ to $1.63 \pm 0.04 \mathrm{mg} / \mathrm{g}$ ). Following exposure the DNA contents decreased prominently. The RNA content 
Table 2. Fluctuations in different biomolecules in the gills of Clarias batrachus at different period of exposure to $1 \mathrm{mg} / \mathrm{L}$ of sodium arsenite. Protein, DNA, RNA, lipid, and glycogen were expressed in $\mathrm{mg} / \mathrm{gm}$ wet wt of tissue. Data are shown as mean \pm SEM $(\mathrm{n}=9)$. (\%) Denote changes over respective controls. Two way ANOVA followed by Dunnett's $t$-test. The criterion for significance differences set at $\left({ }^{*}\right) p<0.05,\left({ }^{* *}\right) p<0.01$ and $\left(^{* * *}\right) p<0.001$ with respective control. ( $\left.{ }^{\text {a }}\right)$ Indicates when exposed groups were compared with 0 day controls and $\left(^{(b)}\right.$, when exposed groups were compared with previous exposed group.

\begin{tabular}{|c|c|c|c|c|c|c|}
\hline \multirow{2}{*}{ Biomolecules } & \multirow{2}{*}{ Treatments } & \multicolumn{5}{|c|}{ Periods (days) } \\
\hline & & 0 & 10 & 30 & 45 & 60 \\
\hline \multirow{2}{*}{ Protein } & Control & $40.88 \pm 1.16$ & $42.11 \pm 0.934$ & $41.22 \pm 0.795$ & $41.44 \pm 0.959$ & $43.66 \pm 1.013$ \\
\hline & Exposed & $40.88 \pm 1.16$ & $\begin{array}{c}37.33 \pm 1.20^{* * \mathrm{a}} \\
(-11.35 \%)\end{array}$ & $\begin{array}{c}32.44 \pm 0.929^{* *} \mathrm{a}, \mathrm{b} \\
(-21.30 \%)\end{array}$ & $\begin{array}{c}24.22 \pm 0.878^{* * *_{a}, \mathrm{~b}} \\
(-41.55 \%)\end{array}$ & $\begin{array}{c}15.66 \pm 0.799^{* * *} \mathrm{a}, \mathrm{b} \\
(-64.13 \%)\end{array}$ \\
\hline \multirow{2}{*}{ DNA } & Control & $7.13 \pm 0.088$ & $7.134 \pm 0.101$ & $6.7 \pm 0.152$ & $7.13 \pm 0.101$ & $6.9 \pm 0.132$ \\
\hline & Exposed & $7.13 \pm 0.088$ & $\begin{array}{c}7.76 \pm 0.044 \\
(+8.77 \%) \\
\end{array}$ & $\begin{array}{c}5.87 \pm 0.09^{\mathrm{a}, \mathrm{b}} \\
(-12.38 \%) \\
\end{array}$ & $\begin{array}{c}6.7 \pm 0.076^{* a, b} \\
(-6.03 \%) \\
\end{array}$ & $\begin{array}{c}4.76 \pm 0.044^{* a, b} \\
(-31.01 \%) \\
\end{array}$ \\
\hline \multirow{2}{*}{ RNA } & Control & $7.03 \pm 0.06$ & $6.80 \pm 0.076$ & $6.93 \pm 0.101$ & $6.66 \pm 0.109$ & $7.3 \pm 0.076$ \\
\hline & Exposed & $7.03 \pm 0.06$ & $\begin{array}{c}7.83 \pm 0.072^{\mathrm{a}, \mathrm{b}} \\
(15.15 \%)\end{array}$ & $\begin{array}{c}7.06 \pm 0.044^{\mathrm{a}, \mathrm{b}} \\
(1 . .88 \%)\end{array}$ & $\begin{array}{c}5.23 \pm 0.116^{*} \\
(-21.47 \%)\end{array}$ & $\begin{array}{c}4.06 \pm 0.066^{* a, b} \\
(-44.38 \%)\end{array}$ \\
\hline \multirow{2}{*}{ Lipid } & Control & $24.77 \pm 0.314$ & $24.47 \pm 0.354$ & $25.63 \pm 0.457$ & $24.75 \pm 0.487$ & $24.44 \pm 0.688$ \\
\hline & Exposed & $24.77 \pm 0.314$ & $\begin{array}{c}21.35 \pm 0.538^{* a, b} \\
(-12.75 \%) \\
\end{array}$ & $\begin{array}{c}20.61 \pm 0.391^{* a} \\
(-19.53 \%) \\
\end{array}$ & $\begin{array}{c}17.57 \pm 1.94^{* a, b} \\
(-28.87 \%) \\
\end{array}$ & $\begin{array}{c}17.91 \pm 0.891^{* * *{ }_{a}} \\
(-26.72 \%)\end{array}$ \\
\hline \multirow{2}{*}{ Glycogen } & Control & $4.62 \pm 0.166$ & $4.18 \pm 0.176$ & $4.022 \pm 0.164$ & $4.544 \pm 0.182$ & $4.011 \pm 0.116$ \\
\hline & Exposed & $4.62 \pm 0.166$ & $\begin{array}{c}4.98 \pm 0.156^{* *} \\
(+19.14 \%) \\
\end{array}$ & $\begin{array}{c}4.044 \pm 0.157^{\mathrm{a}, \mathrm{b}} \\
(+0.55 \%) \\
\end{array}$ & $\begin{array}{c}3.744 \pm 0.138^{* *_{a}} \\
(-17.80 \%) \\
\end{array}$ & $\begin{array}{c}2.488 \pm 0.143^{* * * a, b} \\
(-37.97 \%) \\
\end{array}$ \\
\hline
\end{tabular}

in unexposed control fish during the present tenure of observation also showed periodic fluctuations (between $0.49 \pm 0.01$ to $0.53 \pm 0.002 \mathrm{mg} / \mathrm{g}$ ). Following exposure the RNA content decreased progressively after 10 days of exposure (Table 4). The amount of lipids in the brain of unexposed control fish ranged between $66.16 \pm 0.87 \mathrm{mg} / \mathrm{g}$ (in November) to $73.38 \pm 0.87 \mathrm{mg} / \mathrm{g}$ (in January). In experimental fish the lipid contents of the brain decreased significantly throughout the period of exposure. The decrease was statistically significant throughout the tenure of exposure. The glycogen content in the brain of unexposed control fish ranged between $15.0 \pm 0.003 \mathrm{mg} / \mathrm{g}$ (in November) to $14.6 \pm 0.003 \mathrm{mg} / \mathrm{g}$ (in January). In the exposed tissue the glycogen content after a significant increase (after 10 days), decreased steadily

Table 3. Fluctuations in different biomolecules in the liver of Clarias batrachus at different period of exposure to $1 \mathrm{mg} / \mathrm{L}$ of sodium arsenite. Protein, DNA, RNA, lipid, and glycogen were expressed in $\mathrm{mg} / \mathrm{gm}$ wet wt of tissue. Data are shown as mean $\pm \operatorname{SEM}(\mathrm{n}=9)$. (\%) Denote changes over respective controls. Two way ANOVA followed by Dunnett's $t$-test. The criterion for significance was set at $\left({ }^{*}\right) p<0.05,\left({ }^{* *}\right) p<0.01$ and $\left({ }^{* * *}\right) p<0.001$. $\left({ }^{(a)}\right.$ Indicates when exposed groups were compared with 0 day controls and $(\mathfrak{b})$, when exposed groups were compared with previous exposed group.

\begin{tabular}{|c|c|c|c|c|c|c|}
\hline \multirow{2}{*}{ Biomolecules } & \multirow{2}{*}{ Treatments } & \multicolumn{5}{|c|}{ Periods (days) } \\
\hline & & 0 & 10 & 30 & 45 & 60 \\
\hline \multirow[b]{2}{*}{ Protein } & Control & $80.78 \pm 2.21$ & $81.33 \pm 1.94$ & $89.33 \pm 0.942$ & $83.11 \pm 1.388$ & $88.78 \pm 1.164$ \\
\hline & Exposed & $80.78 \pm 2.21$ & $\begin{array}{c}78.55 \pm 1.35 \\
(-3.42 \%)\end{array}$ & $\begin{array}{c}65.89 \pm 0.715^{* * * a, b} \\
(-26.23 \%)\end{array}$ & $\begin{array}{c}55.77 \pm 1.278^{* * * a, b} \\
(-32.89 \%)\end{array}$ & $\begin{array}{c}40.89 \pm 1.206^{* * * a, b} \\
(-53.94 \%)\end{array}$ \\
\hline \multirow{2}{*}{ DNA } & Control & $2.56 \pm 0.044$ & $2.5 \pm 0.028$ & $2.4 \pm 0.028$ & $2.43 \pm 0.044$ & $2.63 \pm 0.04$ \\
\hline & Exposed & $2.56 \pm 0.044$ & $\begin{array}{c}2.53 \pm 0.116 \\
(+1.2 \%)\end{array}$ & $\begin{array}{c}2.2 \pm 0.028 \\
(-8.33 \%)\end{array}$ & $\begin{array}{l}2.20 \pm 0.028^{\mathrm{a}} \\
\quad(-9.46 \%)\end{array}$ & $\begin{array}{c}2.26 \pm 0.06^{\mathrm{a}} \\
(-14.06 \%)\end{array}$ \\
\hline \multirow{2}{*}{ RNA } & Control & $0.916 \pm 0.007$ & $0.936 \pm 0.006$ & $0.91 \pm 0.007$ & $0.953 \pm 0.007$ & $0.956 \pm 0.006$ \\
\hline & Exposed & $0.916 \pm 0.007$ & $\begin{array}{c}0.836 \pm 0.015 \\
(-10.68 \%) \\
\end{array}$ & $\begin{array}{c}0.736 \pm 0.014 \\
(-19.12 \%)\end{array}$ & $\begin{array}{c}0.673 \pm 0.004^{* a, b} \\
(-29.38 \%)\end{array}$ & $\begin{array}{c}0.576 \pm 0.013^{* a, b} \\
(-39.74 \%)\end{array}$ \\
\hline \multirow{2}{*}{ Lipid } & Control & $55.33 \pm 0.915$ & $53.69 \pm 0.790$ & $53.71 \pm 0.760$ & $54.30 \pm 0.621$ & $56.06 \pm 1.035$ \\
\hline & Exposed & $55.33 \pm 0.915$ & $\begin{array}{c}62.25 \pm 2.269^{*} \\
(+15.94 \%)\end{array}$ & $\begin{array}{c}66.67 \pm 0.748^{*} \\
(+24.13 \%)\end{array}$ & $\begin{array}{c}63.92 \pm 0.852^{*} \\
(+17.72 \%)\end{array}$ & $\begin{array}{c}64.93 \pm 0.724^{*} \\
(+15.82 \%)\end{array}$ \\
\hline \multirow{2}{*}{ Glycogen } & Control & $33.58 \pm 0.621$ & $33.23 \pm 0.633$ & $33.01 \pm 0.569$ & $34.25 \pm 0.608$ & $32.311 \pm 0.568$ \\
\hline & Exposed & $33.58 \pm 0.621$ & $\begin{array}{c}16.91 \pm 0.458^{* * * a} \\
(-49.11 \%)\end{array}$ & $\begin{array}{c}15.17 \pm 0.552^{* * * a, b} \\
(-54.044 \%)\end{array}$ & $\begin{array}{c}13.41 \pm 0.577^{* * * a, b} \\
(-60.84 \%)\end{array}$ & $\begin{array}{c}8.9 \pm 0.551^{* * * a, b} \\
(-72.45 \%)\end{array}$ \\
\hline
\end{tabular}


Table 4. Fluctuations in different biomolecules in the brain of Clarias batrachus, at different period of exposure to $1 \mathrm{mg} / \mathrm{L}$ of sodium arsenite. Protein, DNA, RNA, lipid, and glycogen were expressed in $\mathrm{mg} / \mathrm{gm}$ wet wt of tissue. Data are shown as mean \pm SEM $(\mathrm{n}=9)$. (\%) Denote changes over respective controls. Two way ANOVA followed by Dunnett's $t$-test. The criterion for significance differences set at $\left({ }^{*}\right) p<0.05,\left({ }^{* *}\right) p<0.01$ and $\left(^{* * *}\right) p<0.001$ with respective control. $\left({ }^{(a)}\right.$ Indicates when exposed groups were compared with 0 day controls and $(\mathrm{b})$, when exposed groups were compared with previous exposed group.

\begin{tabular}{|c|c|c|c|c|c|c|}
\hline \multirow{2}{*}{ Biomolecules } & \multirow{2}{*}{ Treatments } & \multicolumn{5}{|c|}{ Periods (days) } \\
\hline & & 0 & 10 & 30 & 45 & 60 \\
\hline \multirow[b]{2}{*}{ Protein } & Control & $35.11 \pm 0.889$ & $34.89 \pm 0.824$ & $37.55 \pm 0.766$ & $37.66 \pm 0.745^{\mathrm{a}}$ & $41.33 \pm 1.66^{\mathrm{a}}$ \\
\hline & Exposed & $35.11 \pm 0.889$ & $\begin{array}{c}35.64 \pm 0.776 \\
(+2.104 \%)\end{array}$ & $\begin{array}{c}31.77 \pm 0.571^{* * a, b} \\
(-15.39 \%)\end{array}$ & $\begin{array}{c}25.33 \pm 0.781^{* * * a, b} \\
(-32.74 \%)\end{array}$ & $\begin{array}{c}22.56 \pm 1.25^{* * a, b} \\
(-45.41 \%)\end{array}$ \\
\hline \multirow{2}{*}{ DNA } & Control & $1.466 \pm 0.044$ & $1.51 \pm 0.028$ & $1.60 \pm 0.06$ & $1.53 \pm 0.060$ & $1.63 \pm 0.044$ \\
\hline & Exposed & $1.466 \pm 0.044$ & $\begin{array}{c}1.43 \pm 0.044^{* \mathrm{a}, \mathrm{b}} \\
(-5.29 \%)\end{array}$ & $\begin{array}{c}1.46 \pm 0.04^{\mathrm{a}, \mathrm{b}} \\
(-8.75 \%)\end{array}$ & $\begin{array}{c}1.33 \pm 0.033^{* * a, b} \\
\quad(-12.87)\end{array}$ & $\begin{array}{l}1.33 \pm 0.044^{* *} \\
(-18.40)\end{array}$ \\
\hline \multirow{2}{*}{ RNA } & Control & $0.496 \pm 0.0164$ & $0.53 \pm 0.005$ & $0.536 \pm 0.004$ & $0.553 \pm 0.007$ & $0.53 \pm 0.002$ \\
\hline & Exposed & $0.496 \pm 0.0164$ & $\begin{array}{c}0.50 \pm 0.004 \\
\quad(-5.6 \%)\end{array}$ & $\begin{array}{c}0.443 \pm 0.006^{\mathrm{a}, \mathrm{b}} \\
(-17.35 \%)\end{array}$ & $\begin{array}{c}0.423 \pm 0.004^{\mathrm{a}, \mathrm{b}} \\
(-23.5 \%)\end{array}$ & $\begin{array}{c}0.376 \pm 0.01^{\mathrm{a}, \mathrm{b}} \\
(-29.05 \%)\end{array}$ \\
\hline \multirow{2}{*}{ Lipid } & Control & $66.16 \pm 0.871$ & $66.789 \pm 0.708$ & $71.733 \pm 0.712$ & $74.044 \pm 0.810$ & $73.389 \pm 0.873$ \\
\hline & Exposed & $66.16 \pm 0.871$ & $\begin{array}{c}51.178 \pm 0.937^{* *} \\
(-23.37 \%) \\
\end{array}$ & $\begin{array}{c}65.789 \pm 0.703^{* \mathrm{~b}} \\
(-8.29 \%) \\
\end{array}$ & $\begin{array}{c}55.933 \pm 0.758^{* * * a, b} \\
(-24.46 \%) \\
\end{array}$ & $\begin{array}{c}48.11 \pm 1.148^{* * a, b} \\
(-34.44 \%) \\
\end{array}$ \\
\hline \multirow{2}{*}{ Glycogen } & Control & $15.0 \pm 0.33$ & $13.9 \pm 0.096$ & $14.8 \pm 0.144$ & $14.3 \pm 0.197$ & $14.6 \pm 0.241$ \\
\hline & Exposed & $15.0 \pm 0.33$ & $\begin{array}{c}15.3 \pm 0.213^{* * * *_{a}} \\
(+10.07 \%)\end{array}$ & $\begin{array}{c}13.1 \pm 0.133^{* * *}{ }^{*, b} \\
(-11.48 \%)\end{array}$ & $\begin{array}{c}12.4 \pm 0.129^{* * * a . b} \\
(-13.28 \%) \\
\end{array}$ & $\begin{array}{c}10.8 \pm 0.115^{* * * a, b} \\
(-26.02 \%)\end{array}$ \\
\hline
\end{tabular}

during the rest of the period of exposure (Table 4). The decrease was statistically significant.

\section{Muscles}

The amount of proteins in the muscles of unexposed control fish ranged between $82.78 \pm 1.42 \mathrm{mg} / \mathrm{g}$ (in November) to $83.66 \pm 1.10$ $\mathrm{mg} / \mathrm{g}$ (in January). The protein contents of the muscles decreased significantly during the entire period of exposure and the loss ranged between 21.72 to $45.42 \%$ (Table 5). The DNA content in the muscular tissue of unexposed fish during the 60 days of observation also fluctuated between $5.63 \pm 0.21$ to $6.1 \pm 0.08 \mathrm{mg} / \mathrm{g}$. In the experimental fish, the decrease was statistically significant only after 45 days of exposure. The RNA content of muscular tissue of unexposed fish during the 60 days of observation also fluctuated but in narrow range (between $5.46 \pm 0.06$ to $5.16 \pm 0.072$ $\mathrm{mg} / \mathrm{g}$ ). In exposed tissue after an initial increase (10 days of the exposure) the RNA contents decreased progressively that were statistically very significant. The lipid contents in the unexposed control tissue were more or less constant ranging between $35.45 \pm 0.55 \mathrm{mg} / \mathrm{g}$ (in November) to $38.11 \pm 0.63 \mathrm{mg} / \mathrm{g}$ (in January). The pattern of fluctuation (ranging between $35.45 \pm 0.55 \mathrm{mg} / \mathrm{gm}$ to $26.74 \pm 1.04 \mathrm{mg} / \mathrm{gm}$ ) in exposed fish was more or less similar to that of RNA. The amount of glycogen in the muscles of unexposed control fish ranged between $3.5 \pm 0.08 \mathrm{mg} / \mathrm{g}$ (in November) to $2.9 \pm 0.117 \mathrm{mg} / \mathrm{g}$ (in January). The glycogen contents of the muscles decreased significantly during the entire period of exposure. (Table 5)

\section{Discussion}

The slime secretion of the skin and gills of fishes protect the fish in many ways. It provides a thick barrier layer which prevents the penetration of the ambient toxicants into deeper layers. In this process the slimy secretion is subsequently sloughed off which costs heavily to the fish as reflected by progressive depletion of protein content of the skin and gills of exposed fish. In the present study the exposure of the arsenic salt was continued for 60 days with maintenance of its concentration by renewing the arsenic solution after every $24 \mathrm{~h}$. Prolongation of exposure damaged the slimy protective layer causing exposure of the different cellular components of the fish to the toxic stress of the arsenic. A review of the tables 1-5 indicates that 60 days of exposure to sodium arsenite causes significant alteration in the protein, nucleic acid, lipid and glycogen contents of skin, gills, liver, brain and muscles of the fish. However the concentrations of these biomolecules fluctuated independently in these tissue components at different periods of exposure. The loss caused by the arsenic salt to the concentration of proteins in the liver was significant after 60 days when it remained only about $54 \%$ of the control value (Table 3 ) indicating great hepatotoxic nature of the arsenic salt. Palaniappan \& Vijayasundram (2008) also demonstrated a decrease in protein quantity of liver of Labeo rohita fingerlings exposed to higher sublethal doses $(41.5 \mathrm{mg} / \mathrm{L})$ of arsenic trioxide for 14 days. Their findings are in contrast to the observation of Irwin (1997) who noticed increased amount of proteins in the liver of C. batrachus following exposure to the pentavalent arsenic salt, sodium arsenate. Depletion in the protein levels of liver and muscles of fishes exposed to different concentration of several heavy metal salts for various exposure periods have also been noticed by James et al. (1991), Jha \& Jha (1995), Palanichamy \& Baskaran (1995), Redy et al. (1998), and Almeida et al. (2001). 
Table 5. Fluctuations in different biomolecules in the muscles of Clarias batrachus at different period of exposure to $1 \mathrm{mg} / \mathrm{L}$ of sodium arsenite. Protein, DNA, RNA, lipid, and glycogen were expressed in $\mathrm{mg} / \mathrm{gm}$ wet wt of tissue. Data are shown as mean \pm SEM $(\mathrm{n}=9)$. (\%) Denote changes over respective controls. Two way ANOVA followed by Dunnett's $t$-test. The criterion for significance differences set at $\left({ }^{*}\right) p<0.05,\left({ }^{* *}\right) p<0.01$ and $\left({ }^{* * *}\right) p<0.001$ with respective control. $\left({ }^{\text {a }}\right)$ Indicates when exposed groups were compared with 0 day controls and (b), when exposed groups were compared with previous exposed group.

\begin{tabular}{|c|c|c|c|c|c|c|}
\hline \multirow{2}{*}{ Biomolecules } & \multirow{2}{*}{ Treatments } & \multicolumn{5}{|c|}{ Periods (days) } \\
\hline & & 0 & 10 & 30 & 45 & 60 \\
\hline \multirow[b]{2}{*}{ Protein } & Control & $82.78 \pm 1.42$ & $84.88 \pm 0.675$ & $76.55 \pm 3.84$ & $79.66 \pm 1.080$ & $83.66 \pm 1.105$ \\
\hline & Exposed & $82.78 \pm 1.42$ & $\begin{array}{c}66.44 \pm 1.740^{* * * a, b} \\
(-21.72 \%) \\
\end{array}$ & $\begin{array}{c}56.88 \pm 1.24^{* * * a, b} \\
(-25.70 \%) \\
\end{array}$ & $\begin{array}{c}53.33 \pm 1.00^{* * * a, b} \\
(-33.05 \%)\end{array}$ & $\begin{array}{c}45.66 \pm 1.536^{* * *_{\mathrm{a}, \mathrm{t}}} \\
(45.42 \%)\end{array}$ \\
\hline \multirow{2}{*}{ DNA } & Control & $5.63 \pm 0.21$ & $5.46 \pm 0.08$ & $5.8 \pm 0.02$ & $5.36 \pm 0.06$ & $6.10 \pm 0.08$ \\
\hline & Exposed & $5.63 \pm 0.21$ & $\begin{array}{c}5.43 \pm 0.04 \\
(-0.55 \%)\end{array}$ & $\begin{array}{l}5.1 \pm 0.02 \\
(-12.07 \%)\end{array}$ & $\begin{array}{c}5.10 \pm 0.07^{*} \\
(-4.85 \%)\end{array}$ & $\begin{array}{c}4.7 \pm 0.13^{* * a, b} \\
(-22.95 \%)\end{array}$ \\
\hline \multirow{2}{*}{ RNA } & Control & $5.46 \pm 0.142$ & $5.53 \pm 0.187$ & $5.6 \pm 0.116$ & $5.5 \pm 0.175$ & $5.16 \pm 0.072$ \\
\hline & Exposed & $5.46 \pm 0.142$ & $\begin{array}{c}6.13 \pm 0.072^{* a} \\
(+10.85 \%)\end{array}$ & $\begin{array}{c}3.21 \pm 0.05^{*}, \mathrm{~b} \\
(-42.68 \%)\end{array}$ & $\begin{array}{c}2.76 \pm 0.044^{* * a, b} \\
(-49.82 \%)\end{array}$ & $\begin{array}{c}1.23 \pm 0.044^{* * *_{a}, \mathrm{t}} \\
(-76.16 \%)\end{array}$ \\
\hline \multirow{2}{*}{ Lipid } & Control & $35.45 \pm 0.553$ & $35.65 \pm 0.429$ & $35.46 \pm 0.448$ & $37.34 \pm 0.540$ & $38.11 \pm 0.636$ \\
\hline & Exposed & $35.45 \pm 0.553$ & $\begin{array}{c}39.62 \pm 0.580^{* a, b} \\
(+11.14 \%)\end{array}$ & $\begin{array}{c}31.77 \pm 0.378^{*}, \mathrm{a} b \\
(-10.40 \%) \\
\end{array}$ & $\begin{array}{c}30.96 \pm 0.500^{* a, b} \\
(-17.09 \%) \\
\end{array}$ & $\begin{array}{c}26.74 \pm 1.036^{* * *_{a}, \mathrm{~b}} \\
(-29.83 \%) \\
\end{array}$ \\
\hline \multirow{2}{*}{ Glycogen } & Control & $3.46 \pm 0.078$ & $3.11 \pm 0.129^{\mathrm{a}}$ & $2.75 \pm 0.148^{\mathrm{a}}$ & $2.85 \pm 0.106^{\mathrm{a}}$ & $2.90 \pm 0.161^{\mathrm{a}}$ \\
\hline & Exposed & $3.46 \pm 0.078$ & $\begin{array}{l}2.32 \pm 0.090^{* * *_{a}} \\
(-25.4 \%)\end{array}$ & $\begin{array}{c}2.09 \pm 0.063^{* * a} \\
(-24 \%)\end{array}$ & $\begin{array}{c}1.66 \pm 0.113^{* * *}, \mathrm{~b}, \mathrm{~b} \\
(-41.75 \%)\end{array}$ & $\begin{array}{c}1.40 \pm 0.108^{* * *_{\mathrm{a}}} \\
(-51.72 \%)\end{array}$ \\
\hline
\end{tabular}

Like liver the protein contents of muscles also decreased (about $45 \%$ ) significantly after 60 days of exposure (Table 1). Exposure to higher sublethal $(21.66 \mathrm{mg} / \mathrm{L})$ value of pesticide dimethoate for 8 days (Begum \& Vijayaraghvan, 1996) also causes decrease in protein concentration of muscular tissue of $C$. batrachus. However the decrease caused by organophosphate insecticide exposure was not so extensive as observed under arsenic stress where the depletion was marked progressive throughout the period of exposure.

Exposure to the arsenic salt did not cause significant alteration in the protein level of the brain prior to 30 days of treatment. Although the toxicity of arsenic on the protein content of the brain manifested late, its concentration fell to about $55 \%$ of the control value after 60 days. This might perhaps be due to the capacity of arsenic to cross the blood brain barrier and accumulate in the brain causing degenerative changes (Rodriguez et al., 2002). Thirumavalavan \& Samipillai (2010) also noticed decreased amount of proteins in the brain of Catla catla exposed to $0.1 \mathrm{ppm}$ of arsenic trioxide. Arsenic induced protein depletion has also been observed in the brain of rat (Samuel et al., 2005).

Following exposure the protein contents of skin and gills decreased substantially. The main reason for protein decrease in these boundary tissues might be due to excessive synthesis followed by sloughing of the slime (made up of glycoprotein) induced by the arsenic stress. For inducing increased secretion of slime in the skin and gills the concentration of RNA also increases (Banerjee, 2007). The other probable reason for the loss of proteins might be due to rejection of damaged cellular components of the skin and gills rendered by the contact stress of different toxicants (Parashar \& Banerjee, 2002; Hemalatha \& Banerjee, 2003;
Chandra \& Banerjee, 2005; Devi \& Banerjee, 2006; Banerjee, 2007), including an arsenic salt (Singh \& Banerjee, 2008). Sloughing of damaged cells from the surface of the skin also causes decreased amount of DNA in the skin exposed to the arsenic solution for prolonged period (Table 1). The contents of both the nucleic acids (DNA and RNA) of the brain and liver decreased throughout the period of exposure indicating malfunction and degenerative changes of these vital organ systems. In rat brain it may also be due to induction of oxidative stress causing DNA damage (Samuel et al., 2005) leading to the decreased synthesis of RNA. Other xenobiotics like carbaryl are also known to cause DNA degenerative changes like necrosis and pycnosis in the nerves of the fish brain (Walsh \& Ribelin, 1975). While the DNA content in the muscles decreases throughout the period of exposure, it increases in the skin. Sloughing of excessive quantity of slime from the body surface may perhaps be one of the main reason for RNA decrease because the slime secreting goblet cells are known to contain large amount of RNA also (Banerjee, 2007). The DNA of the skin increases but only up to 10 days perhaps due to hyperplasia of the epidermal cells a common phenomenon following exposure to various xenobiotics (Rajan \& Banerjee, 1991; Banerjee, 2007), including arsenic (Singh \& Banerjee, 2008c). Due to prolonged continuation of exposure the damaged cells get sloughed off causing decreased level of DNA in the skin beyond 10 days of exposure. The RNA contents of the gills increased up to 30 days of arsenic exposure perhaps due to enhanced production of slime as well as hyperplasia (Singh, 2007) of the branchial epithelia. Due to prolongation of exposure, the different components of the gills including the slime secretary cells get severely damaged causing 
decrease quantity of RNA beyond 30 days of exposure. The reason for increase in the RNA content of the muscles after 10 days when there is marked decrease in protein concentration can not be properly understood. Decrease in RNA content beyond 10 days along with decrease in protein and DNA might be due to degradation of the muscular tissue.

The pattern of alteration in the lipoidal moieties of different organ systems is not identical at different stages of exposure. While the lipid contents in the gills and brain decreased significantly, in liver, they increased and remained above the control level throughout the exposure tenure. Throughout increase in the lipid contents suggests the fatty degeneration of the liver due to disturbed lipid metabolism caused by the arsenic stress (Santra et al., 2007). Begum \& Vijaraghvan (2001) observed significant increase of lipids in the liver and other organ systems of C. batrachus following exposure to carbofuran. According to these authors the maximum enhancement of lipids in liver is due to the fact that the rate of lipogenesis is more in liver as it is the primary organ being affected by the insecticide toxicity. The other reason for the toxicity induced lipid increase might be due to the increased diversity of acetyl Coenzyme A to acetoacetate units for lipogenesis. According to these authors increased oxidative stress may be due to mitochondrial damage within the hepatocytes that in turn caused decreased mitochondrial oxidation of fatty acids. These fatty acids are shunted towards esterification pathways resulting in accumulation of triglycerides within the hepatocytes which seems be true in the present study with C. batrachus also. Arsenic also disturbs the glucose metabolism by uncoupling of oxidation and phosphorylation (Murray et al., 2000) causing excessive availability of unutilized glucose molecules in the tissue. These additional molecules of glucose might later get converted into glycogen or fat causing increased glycogen/lipoidal concentration. Excepting 30 days of exposure when the lipid content of the brain increases, its amount decreases at other stages indicating severe impairment caused to the central nervous system (CNS). Oxidative changes in the CNS induced by arsenic exposure in rodents are well documented (GarciaChavez et al., 2006; Dhar et al., 2005; Flora et al., 2005; Shila et $a l ., 2005 \mathrm{a}, 2005 \mathrm{~b})$. The increase in the lipids in the skin of exposed C. batrachus up to 30 days followed by significant decrease indicates disturbed cutaneous lipid metabolism. The significant increase of lipids in the skin after 10 day onwards up to 30 days might be due to their release from the membrane of the damaged cells. According to Jarrett et al. (1995) phospholipids of the horny cells of the skin of mammals during cornification are mainly derived from the structural membrane lipids of normal cells. Exposure to several heavy metal salts including zinc chloride (Hemalatha \& Banerjee, 1997a, 1997b; Chandra \& Banerjee, 2005 ), lead nitrate (Parasar \& Banerjee, 2002; Devi \& Banerjee, 2006), arsenic (Singh \& Banerjee, 2008a) and manganese (Chatterjee, 2008) are known to cause extensive wear and tear of the gills and skin. On the other hand arsenic causes progressive decrease in the lipid contents of the gills. This is perhaps because arsenic affects the synthesis of lipids necessary as energy reserve (Irwin et al., 1997). Another reason for the decreased lipid contents might perhaps be due to loss of structural membrane of the damaged cells caused by their shedding. Excessive sloughing of the slime from the body and gill surface might also decrease lipid contents because lipids have also been demonstrated in the goblet cells (Banerjee \& Mittal, 1976; Mittal \& Nigam, 1986). Garg et al. (2009) also noticed decreased lipid contents in the gills of three Indian major carps exposed to various combinations of three heavy metals $(\mathrm{Cd}, \mathrm{As}$, and zinc). In the muscles, lipids also decreased progressively but only after 10 days. The decreased lipid contents of the muscles in the later stages might have occurred due to breakdown of lipids to meet the higher energy requirement induced by toxicity (Neelamegam et al., 2006).

In comparison to the proteins, the carbohydrate content of fish tissues are negligible (about 1\% or less) (Borrensen, 1995). The disturbance in the glycogen level is one of the important biochemical lesions due to the stress of ambient toxicants (Elumalai \& Balsubramanian, 1997). The depletion of glycogen from different tissue system of $C$. batrachus following exposure to trivalent arsenic might be due to enhanced utilization of the glycogen as the immediate source to meet the energy requirement under arsenic stress. According to Kumari \& Ahsan (2011) arsenic has definite role in depletion of carbohydrate store which might be a counter active mechanism to fight and survive under toxic environment.

Although the glycogen contents in the muscles and liver in C. batrachus decreased significantly throughout the period of exposure, its level in skin, gills, and brain decreased significantly especially after prolonged (60 days) exposure (Table 1-5). Other stress like various heavy metal contamination (Garg et al., 2009), cold (Haque et al., 2009) exercise (Driedzick \& Hochachkka, 1979) or severe hypoxia (Heath \& Pritchard, 1965) also cause rapid depletion of stored carbohydrate, primarily liver and muscle glycogen. According to Shastry \& Rao (1984) and Naidu et al. (1984) the decreases in the glycogen contents in the muscles and liver of the fish following exposure to heavy metals are species specific perhaps due to their metabolic differences and environmental concentration of heavy metals and duration to which the fishes are exposed. Diwan et al. (1979 ) noticed that decrease in glycogen contents in different organ systems following exposure to industrial effluents (loaded with high concentration of $\mathrm{Cd}, \mathrm{Co}, \mathrm{Cr}, \mathrm{Pb}$, and $\mathrm{Fe}$ ) were different in the same or different fishes. The glycogen content of the brain of arsenic treated C. batrachus showed an initial increase (Table 4). The glycogen level however decreased subsequently on further continuation of exposure. Thirumavalavan \& Samipillai, (2010) also noticed decrease level of glycogen in the brain of C. catla exposed for 21 days to $0.1 \mathrm{mg} / \mathrm{L}$ of arsenic trioxide.

Due to the toxicity of sodium arsenite the levels of glycogen, lipid, protein, and nucleic acids decreased very significantly in most of the tissues illustrating its severe toxicopathological impact on fish subjects. 


\section{Acknowledgements}

The senior author acknowledges the financial support from UGC, Government of India, New Delhi, India in the form of Research Fellowship.

\section{Literature Cited}

Almeida, J. A., E. L. Novelli, M. D. Paisilva \& R. A. Junior. 2001. Environmental cadmium exposure and metabolic responses of the Nile Tilapia, Orechromis niloticus. Environmental. Pollution, 114: 169-175.

Banerjee, T. K. 2007. Histopathology of respiratory organs of certain air-breathing fishes of India. Fish Physiology and Biochemistry, 33: 441-454.

Banerjee, T. K. \& A. K. Mittal. 1976. Histochemistry and functional organization of the skin of a 'Live-fish' Clarias batrachus (Linn.) Mikroskopie, 31:333-349.

Begum, G. \& S. Vijayaraghavan. 1996. Alterations in protein metabolism of muscle tissue in the fish Clarias batrachus (Linn.) by commercial grade dimethoate. Bulletin of Environmental Contamination and Toxocology, 57: 223-228.

Begum, G. \& S. Vijayaraghavan. 2001. Carbofuran toxicity on total lipids and free fatty acids in air breathing fish during exposure and cessation of exposure - in vivo. Environmental Monitoring Assessment, 70: 233-239.

Borresen, T. 1995. Chemical composition. Pp. 138-142. In: H. H. Huss (Ed.). Quality and quality changes in fresh fish. FAO Fisheries Technical Paper 348. Roma: Food and Agriculture Organization of the United Nations.

Carroll, N. V., W. R. Longley \& J. H. Roe. 1956. The determination of glycogen in liver and muscle by use of anthrone reagent. Journal of Biological Chemistry, 220: 583-593.

Cervantes, C., J. G. Ramirez \& J. L. Silver. 1994. Resistance to arsenic compounds in microorganisms. Federation of Europian Microbiological Societies, Microbiology Reviews, 15: 355-367.

Chandra, S. \& T. K. Banerjee. 2005. Estimation of zinc chloride contamination by histopathological analysis of the respiratory organs of the air-breathing "Murrel" Channa striata. Veterinarsky Archiv, 75: 253-263.

Devi, R. \& T. K. Banerjee. 2006. Analyses of the toxicity rendered by lead nitrate on the skin (an accessory respiratory organ) of the air-breathing 'Murrel' Channa striata (Bloch). Biochemical Cellular Archives, 6: 189-199.

Dhar, P., M. Jaitley, M. Kalaivani \& R. D. Mehra. 2005. Preliminary morphological and histochemical changes in rat spinal cord neurons following arsenic ingestion. Neurotoxicology, 26: 309-320.

Diwan, A. D., H. G. Hingorani \& N. C. Naidu. 1979. Level of blood glucose and tissue glycogen in two live fish exposed to industrial effluents. Bulletin of Environmental Contamination and Toxocology, 21, 269.

Driedzic, W. R \& P. W. Hochachka. 1979. Metabolism. Pp. 503543. In: Hoar, W. S. \& D. J. Randall (Eds.). Fish Physiology, Vol. 7. Academic Press New York, USA.

Eisler, R. 1988. Arsenic hazards to fish, wild life and invertebrates: a synoptic review. U.S. Fish and Wild life Service. Biological. Report, 85 (1.12).

Elumalai, M. \& M. P. Balsubramanian. 1997. Effect of naphthalene on carbohydrate metabolism during vitellogenesis in marine edible crab, Scylla serrata. Bulletin of Environmental Contamination and Toxicology, 59: 989- 993.
Flora, S. J. S., S. Bhadauria, S. C. Pant \& R. K. Dhaked. 2005. Arsenic induced blood and brain oxidative stress and its response to some thiol chelators in rats. Life Sciences, 77: 2324-2337.

Folch, J., M. Iers \& G. H. S. Stanley. 1957. A simple method for the isolation and purification of total lipids from animal tissues. Journal of Biological Chemistry, 226, 497-509.

Garg, S., R. Gupta \& K. Jain. 2009. Sublethal effects of heavy metals on biochemical composition and their recovery in Indian major carps. Journal of Hazardous Materials, 163: 1369-1384.

Goering, L. P., V. H. Aposhian, J. M. Mass, M. Cebrian, D. B Beck \& P. M. Walkes. 1999. The enigma of arsenic carcinogenesis: role of metabolism. Toxicological Sciences, 49: 5-14.

García-Chávez, E., A. Santamaría, F. Díaz-Barriga, P. Mandeville, B. I. Juarez \& M. E. Jiménez-Capdeville. 2003. Arsenite-induced production of hydroxyl radical in the striatum of awake rats Brain Research, 976: 82-89.

Haque, M. S., S. K. Roy, M. A. Islam \& N. Roy. 2009. Role of Arsenic on the Regulation of Glycogen Metabolism in Liver of Taki Fishes (Channa punctatus) Exposed to Cold. Thai Journal of Agricultural Science, 42: 159-166.

Heath, A. G. \& A. W. Pritchard. 1965. Effects of severe hypoxia on carbohydrate energy stores and metabolism in two species of freshwater fish. Physiological Zoology, 38: 325.

Hemalatha, S. \& T. K. Banerjee. 1997a. Histopathological analysis of sublethal toxicity of zinc chloride to the respiratory organs of the air-breathing catfish (Heteropneustes fossilis, Bloch). Biological Research, 30: 11-21.

Hemalatha, S. \& T. K. Banerjee. 1997b. Histopathological analysis of acute toxicity of zinc chloride to the respiratory organs of the air-breathing catfish (Heteropneustes fossilis, Bloch). Veterinarsky Arhiv, 67: 1-24.

Irwin, R. J. 1997. Environmental Contaminations Encyclopedia. Arsenic Entry, National Park Service, Water resources Divisions Water Operations Branch Colorado. www.nature.nps.gov/ hazardssafety/toxic/arsenic/pdf

James, R., K. S. Sampath, I. J. Velammal \& J. Kennedy. 1991. Haematological changes in Oreochromis mossambicus as a function of exposure period and sublethal levels of Ekalux. Acta. Hydrobiologica, 35: 73-83.

Jarrett, A., R. I. C. Spearman, P. A. Riley \& A. K. Cane. 1965. The distribution of epidermal phospholipids and their relation to alkaline phosphatase activity in the granular layer. Journal of Investigative Dermatology, 44: 311-319.

Jha, B. S. \& M. M. Jha.1995. Biochemical effects of nickel chloride on the liver and gonads of the fresh water clinging perch. Anahas testadineus (Bloch). Proceedings of the National Academy of Sciences India, 65: 38-39.

Kavitha, C., A. Malarvizhi, S. S. Kumaran \& M. Ramesh. 2010. Toxicological effects of arsenate exposure on hematological, biochemical and liver transaminases activity in an Indian major carp, Catla catla Food and Chemical Toxicology, 48: 2848-2854.

Kumar, R. \& T. K. Banerjee. 2012. Impact of sodium arsenite on certain biomolecules of nutritional importance of the edible components of the economically important catfish C. batrachus (Linn.). Ecology of food and nutrition, 51: 114-127.

Kumari, B. \& J. Ahsan. 2011. Study of muscle glycogen content in both sexes of an Indian teleost Clarias batrachus (Linn.) exposed to different concentrations of Arsenic. Fish Physiology and Biochemistry, 37:161-167.

Leah, R. T., S. J. Envas \& M. S. Johnson. 1992. Arsenic in plaice (Pleuronectus platessa) and withing (Merlangius marlangus) from the north east Irish sea. Marine Pollution Bulletin, 24: 544-549. 
Lowry, O. H., N. J. Rosebrough, A. L. Farr \& R. J. Randall. 1951. Protein measurement with the Folin phenol reagent. Journal of Biological Chemistry, 193: 265-275.

Mittal, A. K \& G. D. Nigam. 1986. Fish skin surface lipids: Phospholipids. Journal of Fish Biology, 29: 123-138.

Murray, R. K., K. Daryl, G. Peter, G. Mayes \& W. Rodwell. 2000. A medical book Harper's Biochemistry. $25^{\text {th }}$ Ed. Los Angeles, California: Lange.

Naidu, K. A., K. Abhinender \& R. Murthi. 1984. Acute effect of mercury toxicity on some enzymes in liver of teleost Sarotherodon mossambicus. Ecotoxicology and Environmental Safety, 8: 215-218.

Neelamegam, P., A. Rajendran, C. Maruthanayagam \& M. Mohanraja. 2006. Study the protein variations induced by Monocrotophos in Cyprinus carpio using PIC16F877 microcontroller. Journal of Scientific and Industrial, Research, 65: 655-658.

Palaniappan, P. L. R. M \& V. Vijayasundaram. 2008. FTIR Study of arsenic induced biochemical changes on the liver tissues of fresh water fingerlings Labeo rohita. Romanian Journal of biophysics, 18:135-144.

Palanichamy, S. \& P. Baskaran. 1995. Selected biochemical and physiological responses of the fish Channa striatus as biomonitor to assess heavy metal pollution in freshwater environment. Journal of Ecotoxicology and environmental Monitoring, 5: 131-138.

Parashar, R. S. \& T. K. Banerjee. 2002. Toxic impact of lethal concentration of lead nitrate on the gills of air breathing catfish, Heteropneustes fossilis (Bloch). Vet Arhiv, 72: 167-183.

Philips, D. J. H. 1994. The chemical forms of arsenic in aquatic organisms and their interrelationships. Pp. 263-288. In: Nriagu, J. O. (Ed.). Arsenic in the Environment. Part I. Cycling and Characteristics. Wiley and Sons, New York.

Rajan, M. T. \& T. K. Banerjee. 1991. Histopathological changes induced by acute toxicity of mercuric chloride on the epidermis of a freshwater catfish Heteropneustes fossilis (Bloch). Ecotoxicology and Environmental Safety, 22: 139-152.

Rao, M. V. \& G. Avani. 2004. Arsenic induced free radical toxicity in brain of mice. Indian Journal of experimental Biology, 42: 495-498.

Reddy, S. J., V. Kalakarni, B. Tharakanadha, D. C. Reddy \& R. Ramamurthi. 1998. Changes in energy metabolism of the fish Labeo rohita in relation to prolonged lead exposure and recovery. Journal of Ecotoxicology and environmental Monitoring, 8: 45-53.

Rodriguez, V. M., L. Carrizales, M. S. Mendoza, O. R. Fajardo \& M. Giordano. 2002. Effects of sodium arsenite exposure on development and behavior in the rat. Neurotoxicology and Teratology, 24: 743-750.

Roy, S. \& S. Bhattacharya. 2006. Arsenic-induced histopathology and synthesis of stress proteins in liver and kidney of Channa punctatus. Ecotoxicology and Environmental Safety, 65: 218-229.

Samuel, S., R. Kathirvel, T. Jayavelu \& P. Chinnakkannu. 2005. Protein oxidative damage in arsenic induced rat brain: Influence of DL- $\alpha$-lipoic acid. Toxicology Letters, 55: 27-34.

Santra, A., A. Chowdhury, S. Ghatak, A. Biswas \& G. K. Dhali. 2007. Arsenic induces apoptosis in mouse liver is mitochondria dependent and is abrogated by $\mathrm{N}$-acetylcysteine. Toxicology and Applied Pharmacology, 220: 146-155.

Sastry, K. V. \& D. R. Rao. 1984. Effects of mercuric chloride on some biochemical and physiological parameters of the fresh water Murrel Channa punctatus. Environmental Research, 34: 343-350.

Schneider, W. C. 1957. Determination of nucleic acids in tissues by pentose analysis. Pp. 680-684. In: Colowick, S. P., N. O.
Kaplan (Eds). Methods in enzymology, vol 3. Academic Press, New York.

Singh, A. K. 2007. Toxicopathological effect of the arsenic salt, sodium arsenate on the respiratory organs of the walking catfish Clarias batrachus (L.). Unpublished Ph.D. Dissertation, Banaras Hindu University, Varanasi, India.

Singh, A. K. \& T. K. Banerjee. 2008a. Toxic impact of sodium arsenate $\left(\mathrm{Na}_{2} \mathrm{HAsO}_{4} \cdot 7 \mathrm{H}_{2} \mathrm{O}\right)$ on skin epidermis of the air-breathing catfish Clarias batrachus (Linn.). Veterinarski Arhiv, 78: 73-88.

Singh, A. K. \& T. K. Banerjee. 2008c. Arsenic-induced biochemical alterations in the respiratory organs (gills, ABOs and skin) of walking catfish Clarias batrachus Linnaeus. Biological. Research, 41: 341-350.

Singh, A. K. \& T. K. Banerjee. 2009. A study on carbohydrate moieties of gills and air-breathing organs of the walking catfish Clarias batrachus (Linn.) following exposure to arsenic. Toxicological \& Environmental Chemistry, 91: 43-52.

Thirumavalavan, R. \& S. Samipillai. 2010. Arsenic induced biochemical changes in the brain tissue of fresh water fish, Catla catla. International Journal of Current Research, 1: 30-34.

Walsh, A. H. \& W. E. Ribelin. 1975. The pathology of pesticide poison-ing. Pp. 515-557. In: Ribelin, W. E. \& E. Migaki (Eds.). The Pathology of Fish. The University of Wisconsin Press Madison.

Submitted July 27, 2011

Accepted February 19, 2012

Published June 29, 2012 